\title{
Gayri Resmi Değer Transfer Sistemlerinin Kara Para Aklama ve Terörizmin Finansmanındaki Rolü: Hawala Sistemi
}

\author{
Burcu GEDIZ ORAL*
}

ÖZ

Gayri Resmi Değer Transfer Sistemleri (Informal Value Transfer Systems-IVTS), fonların veya değerlerin belirli bir coğrafi bölgeyle ilişkisi olan kişisel bir ağ yoluyla bir bölgeden diğerine taşınmasına ilişkin finanansal hizmetlerdir. IVTS dünya çapında yaygın bir sitemdir ve çeşitli meşru ve gayri meşru amaçlar için kullanılmaktadır. IVTS'lerin en yaygın türlerinden biri, kara para aklama ve terörizmin finanse edilmesiyle ilişkilendirilen ve dünya çapında geçerli bir ödeme yöntemi olan Hawala sistemidir. Başlangıçta Hawala ağları Asya'da yüzyıllar önce İpek Yolu boyunca seyahat eden tüccarlar için güvenli para transferleri sağlamıştır. Fakat 11 Eylül 2001'de ABD Dünya Ticaret Merkezi'ne yapılan terörist saldırılardan sonra Hawala uluslararası basında "terörizm için kurulmuş bir bankacılık sistemi”, bir "uluslararası yeraltı bankacılık sistemi” olarak tanımlanmıştır. Bu çalışmada Hawala'nın ortaya çıkışı ve istikrarını sağlayan yönetişim mekanizmaları açıklanmaktadır. Çalışmada bu sistemlerin meşru yönleri korunurken, yasadışı kullanımını sınırlandırmak için etkili düzenleyici politikaların nasıl geliştirilebileceğine odaklanılmaktadır.

Anahtar Kelimeler: Gayri resmi değer transfer sistemleri, Kara para aklama, Terör finansmanı, Hawala sistemi

JEL Sinıflandırması: E44, G23, K20

\section{The Role of Informal Value Transfer Systems in Money Laundering and Financing Terrorism: The Hawala System}

\begin{abstract}
Informal Value Transfer Systems (IVTS) are financial services for moving funds or values from one region to another through a personal network associated with a specific geographic area. IVTS is a widespread system worldwide and is used for a variety of legitimate and illegitimate purposes. One of the most common types of IVTS is the Hawala system, which is a globally valid payment method associated with money laundering and financing of terrorism. Initially, Hawala networks provided secure money transfers for merchants traveling along the Silk Road in Asia centuries ago. However, after the terrorist attacks on the US World Trade Center on September 11, 2001, Hawala was defined as "a banking system established for terrorism", an "international underground banking system" in the international press. In this study, the emergence of Hawala and governance mechanisms that ensure its stability are explained. The study focuses on how effective regulatory policies can be developed to limit the illegal use while protecting the legitimate aspects of these systems.
\end{abstract}

Keywords: Informal value transfer systems, Money laundering, Terrorism financing, Hawala system

JEL Classification: E44, G23, K20

Geliş Tarihi / Received: 25.02.2021 Kabul Tarihi / Accepted: 19.04.2021 Doi: 10.17541/optimum. 886572

\footnotetext{
* Doç. Dr., Manisa Celal Bayar Üniversitesi, Uygulamalı Bilimler Fakültesi, Bankacılık ve Finans Bölümü, gedizburcu@yahoo.com, ORCID: 0000-0001-7096-9288
} 


\section{GİRİş}

IVTS, fonların veya değerlerin belirli bir coğrafi bölgeyle ilişkisi olan kişisel bir ă̆ yoluyla, resmi bir kanıt bırakmadan bir bölgeden diğerine taşınmasına ilişkin finansal hizmetlerdir. $\mathrm{Bu}$ sistemler, geleneksel veya modern sistemler olarak sinıflandırılmaktadır. Geleneksel sistemler, işletmelerin ve bireylerin meşru ihtiyaçlarını karşılamak için geliştirilmiş̧ ve zaman zaman Orta Doğu ve Güney Asya'da resmi bankacılık sistemi haline gelmiştir. IVTS'ler, ucuz, kullanımı basit, belirli formaliteler (kimlik tespiti, ikametgâh beyanı vs) gerektirmeyen uygulamalar olduğundan memleketine para göndermek isteyen göçmen işçi toplulukları tarafından uzun süredir yaygın olarak kullanılmaktadır (Corselli, 2020: 2). Gelişmekte olan ekonomilerde birçok finansal işlem, kurumsal bazda enformel olarak düzenlenmektedir. $\mathrm{Bu}$ da yasal otoriteler tarafindan izlenemeyecekleri ve resmi düzenlemelerin ancak sınırlı bir ölçüde mümkün olabileceği anlamına gelmektedir. Hawala, Mudaraba, Stash House, Fei ch'ien, Phoe Kuan, Casa de Cambio ve Chop Shop en popüler IVTS'lerden bazılarıdır (Corselli, 2020: 2; de Goede, 2003: 513). Bu sistemler temelde çok benzer yöntemler kullansa da bir etnik gruba veya bulunduğu bölgeye bağlı olarak farklı isimlendirilmişlerdir. Bu çalışmada, Hawala en kapsamlı ve en yaygın kullanılan küresel ağ olduğundan hepsini kapsayıcı bir terim olarak kullanılmıştır.

Geleneksel IVTS’ler faaliyet gösterdikleri topluluklar üzerinde ağırlıklı olarak olumlu etkilere sahipken, modern sistemler tam tersi olumsuz etkilere sahiptir. Modern IVTS hiçbir meşru amaç içermeyen suç sistemleri olarak geliştirilmiş, karmaşık işlemlerinden dolayı uyuşturucu kaçakçılığından kara para aklamaya kadar savunmasız olmaları sebebiyle dünya çapında yaygınlık kazanmıştır.

11 Eylül olayları terörizmin finansmanına karşı stratejileri derinleştirmiş ve genişletmiş, terör finansmanı ile mücadele konusundaki uluslararası işbirliğinin zayıflığı sona ermiş ve tüm dünyada, suç faaliyetlerinin tespiti ve kovuşturma yapılabilmesi için finansal istihbarat sağlama ve yasal düzenlemeler yapılması yönünde işbirliği kararı alınmıștır (de Goede 2012: 154; Ryder, 2015: 1). BM Güvenlik Konseyi Kararı (UNSCR), BM Terör Finansmanını Önleme Sözleşmesi'ne (1999) öncelik verilerek, tam uluslararası işbirliği ve terörle ilgili yaptırımlar ve sözleşmelerin ulusal düzeyde uygulanması şeklindedir. Sonuç olarak, 11 Eylül'den önce dört ülke tarafından imzalanan sözleşmeye iki yıl içinde 128 ülke katılmıştır (Cooper ve Walker, 2016: 2). IVTS üzerindeki kontrol talebi, IVTS'nin Birleşmiş Milletler (BM), Mali Eylem Görev Gücü (FATF) ve Uluslararası Para Fonu (IMF) gibi kuruluşlarca dile getirilen, terörizmi finanse etme konusundaki duyarlılığına ilişkin uluslararası endişelerden kaynaklanmaktadır. Bu şüpheler daha sonra IVTS tarafından sunulan riskler ve 11 Eylül saldırılarındaki rollerine ilişkin iddialar hakkında ABD söylemleri ile tetiklenmiştir (Cooper ve Walker, 2016: 1).

Konunun pragmatizmi, fenomen üzerinde daha fazla düşünmeyi ve buna karş1 etkili bir sistem kurmayı gerektirmektedir. Bu bağlamda Hawala sisteminin kara para aklama ve terörizmin finansmanında kullanımında dünya deneyimini incelemek, ekonomik ve mali alanlarda ülkelerin milli güvenliğini sağlamak adına kendi araştırmalarını oluşturabilmesi için önem taşımaktadır. Bu çalışmanın amacı, geleneksel ve modern IVTS kullanımını Hawala sistemi özelinde analiz etmek, gelişimlerinden ve sürekli kullanımlarından sorumlu olan makro göstergeleri belirlemektir. Bu göstergelerin belirlenmesi düzenleyici otoritelerin, sistemlerin meşru yönlerini korurken yasadışı kullanımlarını sınırlandırmak için etkili düzenleyici politikalar geliştirme çabalarına katkı sağlayacaktır. Çalışmada Hawala sistemi, nasıl çalıştı̆̆ 1 ve kalıcı popülaritesinin nedenleri, Hawala'nın kara para aklama ve terör finansmanı suçlarındaki rolü analiz edilmekte, ardından Hawala'yla mücadeleyi hedefleyen yasal ve düzenleyici rejimler özetlenmekte ve eleştirilmekte, mücadelenin zorlukları belirlenip Hawala'nın yasadışı kullanımını kısıtlamak için stratejiler sunulmaktadır. 


\section{IVTS ANALITIK SINIFLANDIRMASI}

Gayri resmi fon transfer sistemleri (IFTS), diğer sistemlere nazaran çok daha eski ve çeşitli etnik grupların kültürüne dayanan bir sistemdir (Bu Çalışmada "geleneksel IVTS" olarak ifade edilmektedir). Bunun tersine gayri resmi değer transferi yöntemleri (IVTM), ticaret modellerini ve finansal uygulamaları etkileyen küreselleşme ve Soğuk Savaş'in sona ermesinin yanı sıra internetin ve teknolojinin gelişmesiyle ortaya çıkmıştır. Aslında IFTS'nin temel mekaniği korunurken, kullanılan araçlar çeşitlendirerek yeni firsatlara adapte olunmuştur. Başka bir deyişle, IFTS ve IVTM'nin birleştiği durumlar olmuştur. Deneysel gerçeklik, IVTS'yi çok katı bir şekilde düşünmektense, geleneksel IVTS'den IVTM'lere doğru sürekli olarak değişen bir dizi modern IVTS'ye işaret etmektedir. IVTS birçok güncel vaka, yöntem ve ağların bir karışımını oluşturur. Bazı ana temalar ve çizilmesi gereken analitik ayrımlar olmasına rağmen, gerçekte değişimin oldukça sık olduğu görülmektedir (Passas, 2003: 22).

IFTS ile IVTM arasındaki ayrım oldukça önemli olsa da aslında IVTS her ikisini de kapsayan daha geniş bir kavram kategorisindedir. Ancak ikincisi neredeyse her zaman suçları ve diğer suistimalleri içerirken, ilki esas olarak meşru müşterilere hizmet vermektedir. Bu şekilde, kontrolörler bir IVTM operasyonu tespit ettiklerinde büyük olasılıkla suç işlendiğini bilirler. Öte yandan, bir IFTS operasyonu tespit ettiklerinde, otomatik olarak suç işlendiğini varsaymamaları gerekir (Passas ve Maimbo, 2008: 177).

Şimdiye kadar belirlenen en önemli IVTS'ler: Hawala ve benzeri sistemler, ayni ödemeler / transferler, hediye hizmetleri, fatura manipülasyonu, e-ödemeler (internet tabanlı ödemeler / transferler), ön ödemeli telefon kartları, çok sayıda kişi tarafından kullanılan kredi / banka kartları, muhabir hesapların kullanılması, aracı hesapların ve banka garantilerinin kullanımı ve hayır kurumları olarak sıralanabilir (Passas, 2003: 7).

Giderek artan sayıda çalışma, diğer suç faaliyetleri gibi terörün finanse edilmesinin de resmi ve gayri resmi yöntem ve ağların bir karışımını içerdiğini keşfetmektedir. IVTS'yi daha derinlemesine incelemek, ulusötesi suçların daha iyi anlaşılmasına katkıda bulunabilir. Ancak iç işleyişlerini anlamadan bu sistemleri düzenleme girişimleri IVTS'leri daha fazla yeraltına iterek daha gizli ve organize olmalarına neden olacaktır (Passas, 2003: 98).

\section{HAWALA SISTEMİ VE İŞLEYIŞ̦i}

Hawala, antik Çin ve Orta Doğu'ya kadar uzanan asırlık bir uluslararası değer transfer sistemidir (El Qorchi, 2002: 31; Milosevic, 2006: 557; Nakhasi, 2007: 475; Rusten Wang, 2011: 211). Hawala ağlarının Asya'da yüzyıllar önce İpek Yolu boyunca seyahat eden tüccarlar için güvenli para transferleri sağladığ 1 düşünülmektedir. Hawala'nın modern gelişimi ise 1947 Hindistan ve Pakistan arasındaki bölünmeye bağlanmaktadır. Yaşanan döviz kontrolleri sonucu, ülkeler arasında para transferi yapmak yasadışı bir hal almış ve Hawala bu boşluğu doldurmuştur (de Goede, 2003: 513). Çok sayıda bölgede ve küresel olarak faaliyet göstermeye devam eden Hawala resmi bankalar, banka havalesi şirketleri ve mobil ödeme hizmetleri gibi güçlü rakipleriyle rekabette dayanıklılığını kanıtlamaktadır. Hawala Avrupa, Kuzey Amerika ve Körfez bölgesine yerleşmiş Güney Asya, Afrika, Latin Amerika gibi yerlerdeki ailelerine para gönderen göçmen işçi toplulukları tarafından yaygın olarak kullanılmaktadır (El Qorchi, 2002: 31; Rusten Wang, 2011: 212). S1kl1kla Müslüman kültürüyle ilişkilendirilmesine rağmen, bu uygulamadaki hiçbir şey İslam geleneğiyle özel olarak ilişkilendirilemez (Parandeh, 2009: 24; Razavy, 2005: 278; Valeri vd., 2020: 1). Çünkü Hawala dini veya kültürel yakınlığına bakılmaksızın tüm müşterilere açık bir sistemdir.

Hawala güvenle eşanlamlıdır (Milosevic, 2006: 557; Nakhasi, 2007: 477). Hawala sistemi, birçok prosedür olmadan kolaylıkla çalışır. Böylece, çok sayıda ücret ve vergi 
ödemekten kaçınılabilir. Bu da sermayelerini başka bir ülkeye anonim olarak taşımak isteyenler için sistemi daha da cazip kılmaktadır (Milosevic, 2016: 557). Hawala sistemi, menşei ülkesinden yabancı bir ülkeye (varış ülkesine) para transferi yapmak isteyen bir kişinin parasını gönderecek olan Hawala Brokerı 1'e (bundan böyle Hawaladar olarak anılacaktır) başvurması üzerine işlemeye başlar (Şekil 1).

A ÜLKESI $\quad$ B ÜLKESI

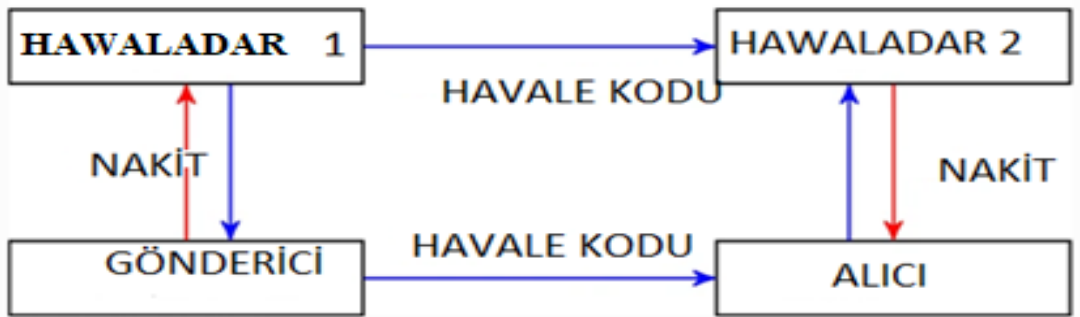

Şekil 1. Hawala Sisteminin İşleyişi

Kaynak: (Gräbner vd., 2020: 2).

Hawaladar 1, hedef bölgedeki başka bir Hawaladar 2 ile telefon, faks veya e-posta yoluyla iletişime geçer, ona aktarılacak para miktarı ve havale kodu hakkında bilgi verir. Daha sonra nihai para alıcısı Hawaladar 2 ile iletişime geçerek havale kodunu verir ve parayı alır. Bu işlem yalnızca birkaç saat sürer (veya çok uzak bölgeler olması durumunda birkaç gün) ve Hawaladarlar, aktarılan miktarın yalnızca yüzde 2 ila 5'i arasında değişen küçük komisyon ücretleri alırlar. Bir transfer tamamlandıktan sonra, işlemin tüm izleri kaldırılır. Hawaladar 1 ve 2 arasındaki ödenmemiş borçlar, tersine havale, paralel mal ticareti veya nakit olarak kuryeler aracılığıyla ödenmektedir (Vaccani, 2009: 5). Yani Hawala'da, fiziksel veya elektronik olarak çeşitli coğrafi konumlar arasında para transferinde bulunulmaz. Bunun yerine, bir dizi takas işlemi gerçekleştirilir. Herhangi bir çift Hawaladar, karşılıklı mali yükümlülüklerini periyodik olarak iptal etmek zorundadır (Lambert, 2002: 360; Razavy, 2005: 280; van de Bunt, 2008: 693).

Tablo 1. Hawala'nın Diğer Suçlarla Benzer ve Benzersiz Özellikleri

\begin{tabular}{llll}
\hline \multicolumn{1}{c}{ Diğer Suçlarla Benzerlikler } & \multicolumn{1}{c}{ Benzersiz Özellikler } \\
\hline Anonim Hesaplar & Müşteriler ve operatörler arasında güven \\
\hline $\begin{array}{l}\text { Kodların kullanımı mesajlaşma ve fonların } \\
\text { hareketleri }\end{array}$ & Dünya çapında daha fazla asimetrik işlem \\
\hline Kayıt eksikliği & $\begin{array}{l}\text { İşlem rotasının bazı kısımlarında kayıt } \\
\text { eksikliği }\end{array}$ & & \\
\hline Ticaretle iç içe olma & Operatörler için ticaretle iç içe olma & \\
\hline Yerleştirme için çok fazla kayıt & Yerleştirme için yasadışı ağların kullanılması \\
\hline Çok fazla yasal para geçişi & & \\
\hline Yetkililere güvensizlik & Terörizme özgü & \\
\hline Dilsel zorluklar & İdeolojik/dini bağlllık \\
\hline Kültürel özellikler &
\end{tabular}

Kaynak: (Passas, 2003: 66). 
Tablo 1'de Hawala'nın diğer suçlarla benzer ve benzersiz özellikleri yer almaktadır. Hawala'yı Batı finansından ayıran başlıca özelliklerden biri Hawala'nın güven ve itibara dayandığ1 gerçeğidir (de Goede, 2003: 515). Hawala kayıtsız, hız, güven ve yerel bilgi mantığıyla çalışmaktadır. Sistem bütünlügü Hawaladarlar arasındaki etnisite, din, sosyal duruş ve iş bağlantılarından kaynaklanan karşılıklı güven üzerine kurulmuştur (Bowers, 2009: 383). Sistemde ișbirliğini sağlayan sosyal kontrol mekanizmalarının, yoğun birbirine bağlılık, gelecekte devam etmesi istenen etkileşim beklentileri ve kişinin itibarını koruma ihtiyacına dayandığ1 varsayılmaktadır (Ballard, 2005: 327; Nakhasi 2007: 481; Razavy, 2005: 280; Schramm ve Taube, 2003: 407). Sistem tarafların kimliğinin, paranın kaynağının veya işlem amacının yakından incelenmesini imkânsız kılmaktadır (Bowers 2009: 385).

$\mathrm{Bu}$ sistemde Hawaladarlar, bankaları ve internet bankacılı̆̆ına dayalı modern ödeme sistemlerini de kullanabilirler. Sistem Hawaladarların yeteneklerini genişleten, coğrafi olarak birbirinden uzak ülkelerde oluşan karş1lklı yükümlülükleri eşitlemek için karmaşık ekonomik planlar uygulayabilmelerine izin veren çeşitli ödeme araçları sağlamaktadır (Dobayev vd., 2020). Hawala şebekeleri müşterilerine bazen kredi de ayarlayabilmektedir. İlke olarak Hawala işlemleri, normal mali kurumlar tarafından yapılan uluslararası para transferlerinden çok farklı değildir. Batı şehirlerindeki Hawaladarlar yeraltında faaliyet göstermezler, çoğu zaman yerel basinda reklam yayınlarlar (de Goede, 2003: 517). Bununla birlikte, resmi olmayan para transferlerinin tanımlayıcı yönü, ulusal hükümetlerin ve uluslararası kurumların resmi muhasebe prosedürlerinden kaçmalarıdır (Choucri, 1986: 697). Öte yandan uluslararası bankalar tarafından yapılan para transferi, resmi olarak ilgili ülkelerdeki ödemeler dengesi rakamlarına kaydedilmektedir.

Sistemde Bitcoin de Hawaladarlar arasındaki transferleri kolaylaştırmak için kullanılabilir. Gönderici, transfer etmek istediği eşdeğer miktarı bir konuma aktarması için Hawaladar 1'e nakit olarak verir. Konumdaki ikinci bir Hawaladar, adresinde Bitcoin alır. Her iki Hawaladar da bu transferi gerçekleştirmek için bir ücret (komisyon) alır. Gönderici hem Bitcoin hem de Hawala işlem ücretlerini öder, ancak kimliğinin doğrulanmasından ve aktarılan tutar için vergi ödemekten kaçınmış olur (Akcora vd. 2020: 2).

Hawala maliyet, işlem hızı, güven, bürokrasinin olmaması ve ayrıntılı incelemelerde bile paranın izinin bulunamaması gibi avantajları nedeniyle gayri meşru kanallar yoluyla elde edilen para transferinde ideal bir yöntemdir. Dünyadaki Hawala sistemlerinde bulunan para miktarını tam olarak ölçmek imkânsızdır. Hawala aracılığıyla aktarılan para miktarı tahminleri 100 milyar dolardan yılda 680 milyar dolara kadar değişmektedir. Bu nedenle Hawala, dünya çapında en önemli IVTS'lerden biri olarak kabul edilir (Catrinescu vd., 2009: 83; Razavy, 2005: 288; Rusten Wang, 2011: 210; Schneider, 2010: 476; Schramm ve Taube 2003: 406; Shehu, 2004: 177; Wheatley, 2014: 348). IVTS yoluyla gerçekleştirilen dünya çapındaki havale hacimlerinin 2020 yılında 666 milyar dolar olduğu, bunun 508 milyar dolarının gelişmekte olan ülkeler tarafindan gerçekleştirildiği tahmin edilmektedir (World Bank, 2020). İtalya'dan yurtdışına yapılan para transferlerinin en az yüzde 30'unu IVTS'nin oluşturduğu tahmin edilmektedir (Corselli, 2020: 2).

\section{KARA PARA AKLAMA / TERÖR FINANSMANI VE HAWALA SISTEMI}

En genel anlamda kara para aklama, suç geliri olarak adlandırılan ve yasadışı yöntemlerle, suç faaliyetlerinden elde edilen kazançla sağlanan geliri veya varlığ amacıyla yapılan her tür eylem olarak tanımlanabilir. Karapara aklama faaliyeti yerleştirme, 
ayrıştırma ve bütünleştirme olarak üç aşamada ${ }^{1}$ gerçekleşmektedir (Gediz Oral ve Gökbunar, 2017: 94).

Terör örgütleri ideolojik odaklı eylemlerini gerçekleştirebilmek için finansman kaynaklarına ihtiyaç duymaktadırlar. Örgütlerin yasal yollardan sağladıkları gelirleri ${ }^{2}$ olduğu gibi yasadışı kazançları ${ }^{3}$ da bulunmaktadır. Aslında terörün finansman kaynaklarının, kişinin hayal gücü ile sınırlı olduğu rahatlıkla söylenebilir. Kara para aklama faaliyetleri de terör örgütlerinin finansmanında çok önemlidir (Gediz Oral, 2016: 345). Karapara aklama yasadış1 fonların kökenini gizleme işlemiyken, terörizmin finansmanı hem yasal hem de yasadışı yollarla elde edilen gelirleri terörist faaliyetler için mali sisteme dâhil etme çabasıdır. Terörizmin finansmanı ve karapara aklamayı ilişkili kılan, karapara aklama tekniklerinin terörizmin finansmanı için de kullanılmasıdır. Ayrıca karapara aklama ve terörizmin finansmanı benzer finans kuruluşları, finansal olmayan işletmeler ve profesyoneller aracılığı ile gerçekleşir. Terörizmin finansmanı ve karapara aklama arasındaki en önemli bağlantı, elinde suç geliri bulunduran örgütlerin gelire el konulmasını engellemek amacı ile aklama tekniklerini kullanmasıdır. Bu nedenle suç örgütleri, söz konusu suç gelirini farklı işlemlere tabi tutarak yasal bir görünüm kazandırmayı amaçlar (Gediz Oral ve Yeşilkaya, 2020: 336-337). Terör örgütlerinin gelir kaynaklarının belirlenmesi ve bu finans kaynakları ile etkin mücadele yürütülmesi terörle mücadelenin başarısının en önemli belirleyicilerindendir (Gediz Oral, 2016: 354).

Son yıllarda dünya genelinde küreselleşme süreçleri ve internetin yaygınlaşmasıyla Hawala'nın dönüşümü gerçekleşmiş, Hawala organize suç gruplarının suç faaliyetlerinde sıklıkla kullanılır hale gelmiştir. $\mathrm{Bu}$ bağlamda, Hawala sistemi aracılığıyla finansal işlemlerin kriminolojik özelliklerinin incelenmesi özel bir önem kazanmıştır. ABD'de bu soruna ancak 11 Eylül 2001 terörist saldırılarından sonra dikkat edilmeye başlanmış, ancak şu ana kadar istenmeyen finansal akışları tamamen engellemek mümkün olmamıştır (Dobayev vd., 2020). Bilimsel çalışmalar, yetkililer tarafından yapılan açıklamalar ve son yıllardaki uluslararası yayınlar, Hawala sisteminin suç faaliyetlerinde (terör finansmanı, kara para aklama, vergi kaçakçılığı, uyuşturucu ticareti, silah ticareti, değerli taş-maden kaçakçılığı, kayıt dışı ekonomi, yolsuzluk vb.) kullanımına dikkat çekmektedir (Ballard, 2006: 2; Stepanova, 2005: 305-310; Milosevic, 2016: 558).

Resmi bankaların kara para aklama karşıtı yasalarla karşı karşıya kaldığ 1 bir dönemde, Hawala'nın gayri resmi karakteri, kara para aklamayla mücadelede giderek zayıf bir halka olarak görülmektedir (van de Bunt, 2008: 692). Hawala'nın anonimlik ve resmi inceleme eksikliği gibi özellikleri onu suiistimale açık hale getirmektedir (Razavy, 2005: 288). Bu endişelere rağmen, bugüne kadar Hawala'nın kötüye kullanımına ilişkin yeterli deneysel materyal yayınlanmamıştır. $\mathrm{Bu}$ "gizli fenomen" hakkında fikir edinmenin bir yolu, polis dosyalarını incelemektir. İlgili dosyalarda dinlenen telefon görüşmelerinin raporları, el konulan hesapların kopyaları, şüphelilerin sorgulama tutanakları, tanık ifadeleri vb. yer almaktadır. Bu dosyalar, Hawala'nın

\footnotetext{
1 Yerleştirme aşamasında, para finansal sisteme girmektedir. Ayrıştırma aşamasının amacı parayı yasadışı kaynağından uzaklaştırıp, bir dizi karmaşık işlemle paranın izini kaybettirmektedir. Son aşama tüm fonların yasal işlerden elde edilmiş gibi toplanmasını içermektedir (Gediz Oral ve Gökbunar, 2017: 94).

${ }^{2}$ Terör finansmanın en yaygın yasal kaynaklarından bazıları şunlardır (Gediz Oral, Koç, 2010: 196-197; Yücebaş, 2011: 198-204):

Hayır kurumlarından, STK'lardan ve diğer devletlerden sağlanan yardımlar, ticari işletmelerden sağlanan kazançlar, kültürel etkinlikler ve bağıș toplama, hisse senedi, gayrimenkul vb. yatırımlar.

${ }^{3}$ Terörün illegal finansman kaynakları şunlardır (Gediz Oral ve Koç, 2010: 197-199; Yücebaş, 2011: 206-218):

Kaçakçılık (uyuşturucu madde, silah, insan, altın, değerli taş vs), haraç, adam kaçırma, soygun, gasp, sahtecilik ve dolandırıcılık, korsan ürün ticareti, aidat gelirleri, örgütsel yayın gelirleri.
} 
işleyiş̧ine ilişkin ayrıntılı ve gerçek bilgiler sunarken, uluslararası ağının boyutuna ilişkin bilgi eksikliği devam edecektir. Polis dosyalarından toplanan bilgilere dayanarak elde edilecek mevcut katkı, Hawala'nın yasadışı amaçlarla kullanılabilme yollarını incelemek olacaktır (van de Bunt, 2008: 692).

Hawala sistemi aracılığıyla Hindistan halkına yönelik terörist operasyonların finanse edildiği tespit edilmiştir. 2000 yılında, Red Fort şehrinde, Lashkar-e-Taiba terörist grubunun üyeleri, Dubai'de faaliyet gösteren bir Hawaladardan 3,5 milyon rupi almış ve üç Hint askerini öldürmüştür. Adı geçen terörist grup, 2008 yılında Mumbai'de de terörist saldırılara karışmıştır. 1993'ün başlarında, Mumbai'de bir dizi terörist saldırı gerçekleştiğinde, paranın yerel Hawaladar tarafından Lashkar-e-Taiba'nın terörist üyelerine aktarıldığ Afganistan'daki yerel askeri operasyonları sırasında, Hawala sistemi aracılığıyla Pakistan'dan mücahitlere para transfer edilmiştir (Dobayev, 2020). 11 Eylül 2001'de Amerika Birleşik Devletleri'ndeki saldırıları soruşturan komisyonun çalışmalarında, Bin Ladin'in Dubai, Pakistan ve Ortadoğu'da faaliyet gösteren Hawaladar ağını suç faaliyetlerinde kullandığı tespit edilmiştir (Cooper ve Walker, 2016: 1; Dobayev, 2020). Terörist saldırıların Hawala sistemiyle bir başka bağlantısı 1998 yılında Nairobi'deki büyükelçiliğe yapılan terörist saldırıda, teröristlerden birinin kaçarak Yemen'den Hawaladar aracılığıyla aktarılan parayı almasıdır (Dobayev, 2020). Somali'deki bir Hawala olan Al Barakaat'nn, terör örgütleri tarafından para transferi yapmak için kullanıldığına dair kanıtlar olduğundan, 2001-2009 yılları arasında faaliyetleri dondurulmuştur. Ayrıca, El-Kaide ile ilişkili olanların Hawala sistemini kullanarak varlıklarını taşıdıkları düşünülmektedir (Bowers, 2009: 411). Hindistan'a Hawala kanallarından gelen havale akışlarının, ülke GSYİH'sinin yüzde 40'1 olduğu tahmin edilmektedir (Razavy 2005: 288). Pakistan'da ise Hawala para akışının yılda 2-5 milyar dolar aralı̆̆ında olduğu tahmin edilmektedir (Wheatley, 2014: 353).

Passas (2003) Hawala sistemi ile sistemin suç faaliyetlerinde kullanımı arasında paralellik kurarak Hawala'yı sınıflandırmıştır (Passas, 2003: 68). FATF bu sınıflandırmayı biraz daha geliştirilerek sistemin en doğru sınıflandırmasını önermiştir (FATF, 2013: 14-15):

- Saf Geleneksel Hawala: Belirli bir etnik grubun kültürel özellikleriyle yakından ilişkili eski sistemlerdir. Hawaladar, esas olarak sistemde dolaşan yasal kökenli parayla meşru ihtiyaçlara hizmet eder. Burada esas olarak Hawaladarların kara para transfer edebileceği, ancak bunların hacminin önemsiz olduğu kabul edilmektedir.

- Hibrit Geleneksel Hawala: İnternet, teknoloji ve küreselleşme süreçlerinin gelişmesiyle güçlü bir ivme kazanmıştır. Tamamen yasal değildir, çünkü Hawaladar kasıtsız olarak yasadışı faaliyetlere katılabilir.

- Yasadışı Hawala: Hawaladar kasıtlı olarak bir suç kanalının düzenleyicisi (terörist grupların finansmanı; suç gelirlerin yasallaştırılması; ülkeden yasadışı fonların çekilmesi) veya suçlulara bu hizmetleri sağlayan bir suç ortağı olarak hareket eder. Bu alan, aynı anda birkaç açıdan oldukça karmaşıktır. Birincisi, bu alandaki hareketin yönü gelişmiş ülkelerden gelişmekte olan ülkelere doğru olabileceği gibi, tam tersi yönde de olabilir. Hawala sistemi aracılığıyla yapılan transferler, çok sayıda aracı ve ülke içerebilir. İkinci olarak, transfer zincirleri çerçevesinde karşılıklı talepleri eşitlemek için çok çeşitli ödeme araçları kullanılabilir. Muhasebeleştirilmemiş varlıklar (nakit, kıymetli taşlar, kıymetli madenler ve diğer likit değerler) Hawaladarlar arasında uzlaşmaya konu olup, aktarılan maddi değerler nakit veya nakit olmayan biçimde değiştirilebilir. Sistemde denetçiler tarafından düzenlenmeyen işlem türleri de kullanılabilir, bu nedenle resmi bankacılık sisteminin dışında kalabilir. Son olarak, operatörlerin başlangıçtaki amacının suç gelirlerini yasal sisteme yerleştirmek olduğu unutulmamalıdır. Karş11ıklı ödeme sürecinin, olası kara para aklama ile mücadele açısından kolluk kuvvetleri ve denetim makamları tarafından izlenmesi oldukça güçtür (Dobayev, 2020; Passas, 2003: 71). Passas (2003)'e göre, devletlerin güvenliğine yönelik en büyük tehdit bu alandır. Bunun nedeni, 
özellikle büyük ölçekte para transferi için mevcut olan firsatlardır. Hawala sisteminin suçlular tarafindan kullanılabilecek bir sisteme dönüşebileceği unutulmamalıdır. Özellikle, Hawaladar tarafindan kullanılan para miktarı arttıkça sistem daha da cazip hale gelmektedir (Passas, 2003: 71).

Teicman ve Falker (2020) Hawala gibi yeraltı bankacılık sistemlerinin mevcut kara para aklama ve terör finansmanıyla mücadele önlemlerini atlatmak için nasıl kullanılabileceğini araştırdıkları çalışmalarında, yeraltı bankacılığını kullanan 50 suçlu ile gayri resmi ve 50 uyum uzmanı $^{4}$ ile de resmi görüşmeler yapmışlardır. Görüşmelerin bulgularını nitel içerik analizi ile analiz edip, 200 uyum uzmanıyla da anket yapmışlardır. Çalışmadan elde edilen sonuçlara göre, Hawala mutlaka yasadışı faaliyetler için kullanılmamaktadır. Fakat sistem kara para aklama ve terörizmin finansmanı amaçlarına son derece uygun olduğundan yasaklanmalıdır. Hawala'nın ana amac1, düzenli veya güvenilir bir bankacılık sistemine erişimi olmayan bölgelere para transferlerini kolaylaştırmak olsa da sistem genellikle suçlular tarafindan istismar edilmektedir.

Hawala'nın terör finansmanı için bir güvenlik açığı oluşturmasının temel sebepleri, mali denetim eksikliği, bankacılık sistemi dışında birden çok yargı alanında ödeme yapılabilmesi, düzenlemeye tabi olan finansal kurumların ve hiçbir düzenlemeye tabi olmayan işletmelerin birarada kullanımı, uluslararası net bir uzlaşmanın olmaması, yasal ve yasadışı gelirlerin karıştırılması olarak belirtilmektedir. Düzenlenmemiş sektörü düzenlenmiş alana çekmek için çabaların yetersizliği ve kayıt dışı kuruluşlara karşı yaptırım uygulanmaması, düzenlemeye tabi olmayan kuruluşların, düzenleme ve denetime tabi tutulmaları için gerekli teşviki en aza indirmektedir (FATF, 2013: 41).

\section{HAWALA SISTEMININ ÍSTISMARI ILE MÜCADELEDE MEVCUT DURUM}

Hawala sisteminin istismarı ile mücadelede mevcut durum yasaklayıc1 ve kısıtlayıc1 tedbirler, kara para aklama ve terör finansmanıyla mücadele yasaları, Hawala operatörlerini kayıt altına alma çabaları, bankacılık sektöründeki kurumsal eksiklikleri giderme ve işlem maliyetlerini düşürme çabaları başlıkları altında ele alınacaktır.

\subsection{Yasaklayıcı / Kısıtlayıcı Tedbirler}

Günümüzde birçok ülkede otoritelerin karşılaştığ temel zorluklardan biri, Hawala ve diğer benzer hizmet sağlayıcılarının nasıl düzenlenip denetleneceğidir. IVTS için denetim kaynaklarının eksikliği küresel bir sorundur. Diğer sektörlerde olduğu gibi, IVTS ne kadar az düzenlenir ve denetlenirse, kara para aklama ve terörün finansmanı kırılganlığı o kadar büyük olacaktır. Düzenlenmemiş operatörler kara para aklama ve terör finansmanı risklerine karşı savunmasızdır (FATF, 2013: 26).

Bu sorunu çözmek için Fransa, Hindistan, İran, Malezya, Portekiz, İspanya, Venezuela ve Pakistan gibi bazı devletler IVTS'yi yasadışı hale getirmiştir. Kanada, Almanya, Hollanda, Paraguay, Katar, Kore Cumhuriyeti, Singapur, İsveç, Suriye, İngiltere ve ABD IVTS'yi düzenleyici denetime tabi tutmuştur. Bununla birlikte bu kısıtlamaların, gerçekte sistemlerde bulunan veya bu sistemler aracılığıla aktarılan para miktarı üzerinde çok az etkisinin olduğu düşünülmektedir (Bowers, 2009: 385; Gräbner vd., 2020: 4; Gordon-Rossman, 2009: 4-5; Wheatley, 2014: 378). Çünkü teröristler altın, pırlanta ve diğer emtia yoluyla da kara para

\footnotetext{
${ }^{4}$ Uyum Uzmanı / Görevlisi: Suç gelirlerinin aklanması ve terörün finansmanın önlenmesi (AML/CTF) mevzuatına ilişkin olarak bankanın risk yönetimi, izleme ve kontrol faaliyetlerini yürüten kişidir (Resmi Gazete 26999).
} 
aklayabilmekte ve devletler nakit dışı varlıkları dondurmada güçlük çekmektedir (Burns, 2006: 4).

Resmi hukuk sistemi Hawala operasyonlarını düzenlemeye veya hatta bazı yerlerde tamamen yasaklamaya çalışsa da bu tür bir IVTS, yasal baskılara rağmen kayda değer bir dayanıklılık göstermekte ve faaliyetler çoğunlukla gayri resmi bir şekilde sürdürülmektedir (Razavy 2005: 288). Resmi politikalardaki belirsizlikler nedeniyle Hawaladarlar, resmi olmayan normlar ve gelenekler sistemi tarafından yönetilen devreler oluşturarak, kapalı bir topluluk olarak çalışmaya devam etmektedir. Hawala'ya belirli bir bölgede izin veriliyor, ancak devlet kurumları tarafından yoğun bir şekilde incelenmesi ve düzenlenmesi öngörülüyorsa dikkat edilmesi gereken konu, genel olarak sistemin şeffaf olmayacağıdır. Böylece yetkililer, A acentesinden B temsilcisine belirli bir miktar para transfer edildiğini teyit etmek için büyük çaba sarf etmek zorunda kalacaklardır. Bu nedenle, Hawala'yı yasal kontrol altına almaya yönelik tüm girişimlere rağmen bu tür bir IVTS, kendi alanındaki süreçleri ve ilişkileri belirleyen kayıt dışılı̆̆ını büyük ölçüde korumaktadır (Gräbner vd., 2020: 5).

\subsection{Kara Para Aklama ve Terörle Mücadele Yasaları}

1970'lerde dünyada başta ABD'de olmak üzere vergi kaçakçılığında uluslararası bankaların kullanımı ile mücadele etmek için geliştirilen kara para aklama kontrolleri, zamanla uyuşturucuyla savaşın önemli bir bileşeni haline gelmiş, daha sonrasında sigara kaçakçılığından, yolsuzluğa ve terör finansmanına kadar geniş bir yelpazede yer alan suçlarla mücadele eden kapsamlı ve global bir kontrol kümesi haline gelmiştir (Levi ve Reuter, 2008: 290). Kara para aklama ve terör finansmanıyla mücadele önlemleri (Anti-Money Laudering / Combating the Financing of Terrorism - AML / CFT) mali sistemin güvenliğini ve sağlamlığını korumak için tasarlanan kurallardan temelde farklıdır. Bu önlemler oluşturulmadan önce, bankaların suçluların yakalanmasındaki rollerini tam olarak kavradıklarını söylemek mümkün değildir. AML / CFT arasındaki bağlantı da açık değildir. AML dolandırıcıların kara parayı bir banka veya başka bir finansal kurum aracılığıyla çalıştırmasını ve suç gelirleri olduğunun saklanmasını önlemek için tasarlanmıştır. CFT ise paranın kaynağından ziyade paranın nihai kullanımı üzerine daha ciddi olarak odaklanmaktadır (Gordon ve Rossman, 2009: 2).

AML / CFT'de merkezi bir aktör, mali sistemin suçlular tarafından kullanılmasına karş1 koymak üzere tasarlanan tedbirleri kabul etmek ve uygulamak üzere tasarlanmış bir uluslararası organ olan Mali Eylem Görev Gücüdür (FATF). FATF'ın 40 tavsiyesi temelde üç konu alanına ayrılabilir: - ceza kanunu - uluslararası işbirliği - finansal kurumlar için önleyici tedbirler. Önleyici tedbirler ${ }^{5}$ banka gizliliğini yasaklama, müssteri hesaplarının kara para aklamayı gösterebilecek şüpheli işlemlerin izlenmesi ve ilgili resmi makamlara bildirilmesi gibi konuları içermektedir (Wheatley, 2014: 370-372).

ABD, Birleşik Arap Emirlikleri, Pakistan ve Hindistan'ın Hawala yasaları ve uluslararası örgütler tarafından önerilen yasal rejim incelendiğinde, bu yasalar ve tekliflerin, kayıtlara dayalı bir yaklaşım izlediği, lisanslama, detaylı kayıtlar ve şüpheli işlem raporları ile karakterize edildiği rahatlıkla görülebilecektir. Bununla birlikte Hawala, doğası gereği bu yasal hükümlere karşı bir meydan okuma oluşturmakta ve bu işlemlerden kaçınmaktadır (Wheatley, 2014: 364).

\footnotetext{
${ }^{5}$ FATF'in 40 Tavsiyesindeki “önleyici tebirler”; FINANSAL KURULUŞLARA İLİŞKİN GİZLİLİK YASALARI, MÜŞTERININ TANINMASI VE KAYITLARIN SAKLANMASI (Müşterinin Tanınması, Kayıt Tutma), BELIRLİ MÜŞTERILER VE FAALIYETLER İÇIN İLAVE TEDBİRLER (Siyasi Nüfuz Sahibi Kişiler, Muhabir Bankacılık, Para veya Değer Transferi Hizmetleri, Yeni Teknolojiler, Elektronik Transferler) GÜVEN, KONTROLLER VE FINANSAL GRUPLAR (Üçüncü Taraflara Güven, İç Kontroller ve Yurt Dışı Şube ve Bağlı Kuruluşlar, Yüksek Riskli Ülkeler) ŞÜPHELİ İŞLEM BİLDİRİMİ (Şüpheli İşlem Bildirimi, Bilgi Sızdırma ve Gizlilik) FINANSAL OLMAYAN BELIRLİ İş VE MESLEKLER başlıklarından oluşmaktadır (FATF, 2012-2020: 6).
} 


\subsection{Operatörleri Kayit Altına Alma}

Son zamanlarda kayıt dışı transferlerin kayıt altına alınmasına büyük önem verilmiş, IVTS operatörlerinin lisans almaları, işlemlerini bildirmeleri ve AML / CFT yasalarına uymaları zorunlu tutulmuştur. Örneğin ABD'deki mevcut politika, federal düzeyde kayıt ve eyalet düzeyinde lisans almayı gerektirir. IVTS'nin kapsamına giren tüm ana operatörler, Mali Suçlar Uygulama Ağı'na (FinCEN) kaydolmalı ve AML ve CFT prosedürlerini yürürlüğe koymalıdır (Passas, 2006: 325). Ancak eyaletler kendi lisans gereklilikleriyle hem tutarsizdir hem de IVTS'nin ölçeği ve müşteri tabanı dikkate alınmamaktadır. Bir IVTS başlatmak için parasal gereklilik, eyaletler arasında, 15.000 ila 1,5 milyon ABD Doları arasında değişmektedir. Bu, Kanada'da sıfirdan Fransa'da 2,4 milyon Euro'ya kadar değişen düzenleme maliyetleri ile diğer ülkelerde de geçerlidir (Passas, 2006: 323). Görüldüğü gibi uluslararası koordinasyon oldukça tutarsız ve düzensizdir. IVTS işlemlerinin büyük çoğunluğu meşru amaçlara yönelik olsa da 11 Eylül'den sonra kullanımlarını kısıtlama çabaları, bu işlemlerin benzersiz özelliklerini (bknz. Tablo 1) hesaba katmamıştır. FATF'ın IVTS yaklaşımı, ağırlıklı olarak resmi bankacılık sektörü için mevcut uluslararası AML standartlarını gayri resmi sektöre aktarmak olmuştur. FATF tavsiyeleri ayrıca tüm IVTS operatörleri ve aracıları için derinlemesine arka plan araştırmaları gerektirmektedir (Passas, 2006: 325).

\subsection{Bankacılık Sektöründeki Kurumsal Eksiklikleri Giderme ve İşlem Maliyetlerini Düşürme}

IVTS'nin kullanımını etkileyen önemli makroekonomik sorunlardan biri de küresel bankacılık sistemindeki kurumsal eksikliklerdir. Küresel bankacılık sistemi işlemleri düşük maliyetli, etkin ve verimli bir şekilde gerçekleştirememektedir. Bu transferleri gerçekleştiren kişiler genellikle düşük gelirli müşterilerdir ve "birincil müşteriler" olarak kabul edilmezler. Küçük transferler bankalar için daha maliyetlidir ve yüksek havale ücretleri gelişmekte olan ülkelerden gelen bireyleri sistemden uzaklaştırmaktadır. Ayrıca 11 Eylül'den bu yana yürürlüğe giren daha katı Müşterinizi Tanıyın kuralları, çoğu durumda, banka havalesi göndermek için hem gönderenin hem de alıcının bankada bir hesabı olması gerektirmektedir. Hesap açmak için kimlik ve ikametgâh kanıtı gereklidir. Birçok göçmen işçi bu tür belgeleri sağlayamamaktadır (Malakoutikhah, 2020; Elmi ve Ngwenyama, 2020).

Resmi bankacılık sistemine erişimi sınırlayan yapısal ve düzenleyici konuların yanı sıra, bankaların fiziksel konumu da önemli bir caydırıcıdır. Fonlar genellikle bankalar tarafindan hizmet verilmeyen kırsal alanlara gönderilir. Gelişmekte olan ülkelerin çoğunda bankalar, öncelikle kentsel alanlarda bulunduğundan, uzak köylere fon taşıma konusunda sınırlı kapasiteye sahiptir. Bu gerçek, gelişmiş ülkelerdeki IVTS'yi kapatmaya yönelik bazı düzenleyici çabalarla büyük bir çelişkiyi vurgulamaktadır. Bazı bankalar kentsel alanlardaki bankalardan kırsal köylere kurye hizmetleri sunmaya başlasa da bunlar genellikle yavaş ve güvenilmezdir. Belirli bir ülkeden transfer yöntemini etkileyen en önemli faktör, eve yakın bir hizmet noktasıyla bağlantılı olan para transferi hizmetlerinin kullanılabilirliği ve bu hizmetlere erişim imkânı olmaktadır (Malakoutikhah, 2020; Elmi ve Ngwenyama, 2020).

Dünya çapında havale maliyetlerinin düşülmesi amacıyla, Dünya Bankası 2009 yılından beri, Dünya Çapında Havale Fiyatları Sistemi (Remittance Prices Worldwide- RPW) ile dünyanın tüm coğrafi bölgelerinde havale fiyatlarını izlemektedir. Veri tabanı her üç ayda bir güncellenerek kullanıma sunulmaktadır. Veri tabanı 48 gönderici ve 105 alıcı ülkeyi izlemektedir. RPW, hükümetler, hizmet sağlayıcılar ve diğer paydaşlarla ortaklaşa sürdürülen G20'nin küresel ortalamayı yüzde 5'e düşürme taahhüdü de dâhil olmak üzere, küresel maliyetleri azaltma hedeflerine yönelik ilerlemeyi ölçmek için bir referans olarak 
kullanılmaktadır. 2020’nin 4. çeyreğinde küresel olarak, havale gönderme maliyeti, gönderilen miktarın ortalama yüzde 6,51'i kadardır (World Bank, 2020: 1-5).



Şekil 2. G20 Ülkelerinden Ortalama Havale Gönderme Maliyeti (2020)

Kaynak: (World Bank, 2020: 10).

Şekil 2'ye göre 2020'nin 4. Çeyreğinde G20 ülkelerinden gönderilen havalelerde en maliyetli ülke yüzde 14,41'lik oranla Güney Afrika'dır. En maliyetli ikinci G20 gönderen ülkesi olan Japonya'dan havale gönderme maliyeti yüzde 10,02'dir. 2020 4. çeyreğinde yüzde 1,00 ile en düşük G20 gönderen ülke olan Rusya, onu Suudi Arabistan (yüzde 4,42) ve Kore Cumhuriyeti (yüzde 4,74) izlemektedir.

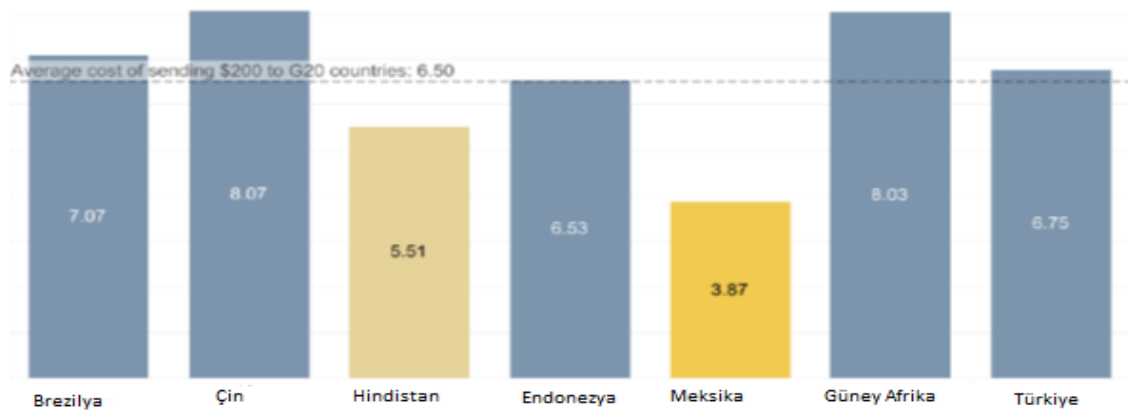

Şekil 3. G20 Ülkelerine 200 ABD dolar Göndermenin Toplam Ortalama Maliyeti (2020)

Kaynak: (World Bank, 2020: 11).

Şekil 3 2020'de G20 ülkelerine 200 ABD doları göndermenin toplam ortalama maliyetini göstermektedir. G20 ülkelerine ortalama havale gönderme maliyeti 2020'nin 4. çeyreğinde yüzde 6,50 olarak kaydedilmiştir. Çin yüzde 8,07 en maliyetli ülke, hemen arkasından Güney Afrika gelmektedir. Maliyetin en düşük olduğu ülke ise yüzde 5,51 ile Hindistan'dır. Hawala birçok ülkede, ekonomiye aşırı hükümet müdahalesi, yasal yaptırımların ve vergi yüklerinin ağırlığının finansal kurumların gelişmesini engellemesiyle, ekonomik koşullara tepki olarak ortaya çıksa da aslında küresel bankacılı̆̆ın kar maksimizasyonu güdüsüyle de yakından bağlantılıdır. Hawala'ya kıyasla, finansal kurumlar daha fazla maliyet ve daha yavaş hizmet koşullarıyla yüzleşene kadar Hawala popüler kalacaktır (Burns, 2006: 10; Wheatley, 2014: 378). 


\section{HAWALA İLE MÜCADELEDE MUHTEMEL STRATEJILER}

Yasadışı Hawala ile mücadele stratejileri, araştırma teknikleri ve Hawala’ya alternatifler geliştirmek için ekonomik teşvikler olarak iki kategoriye ayrılabilir. Her iki durumda da gelişmiş ülkeler ve uluslararası örgütler, beceri ya da fonlardan yoksun olan devletlere (başta gelişmekte olan ülkelere) yardımda bulunmalıdır. Bu yardımlar özellikle de eğitim ve kapasite geliştirme konularında olmalıdır (Wheatley, 2014: 374). Hükümetler ve özel sektör Hawala'ya yönelik alternatifleri teşvik edebilir. Örneğin Hindistan hükümeti, Western Union ile ülke genelindeki şehirlerde faaliyet göstermek için ulusal posta servisi arasındaki bir ortaklığı onaylamıştır. Ayrıca Western Union, Pakistan Merkez Bankası ile havale hizmetleri sunmak için ortaklık kurmuştur. Mısır, Ürdün, Lübnan ve İran'daki döviz şirketleri, Filipinler'deki bankalar kapıdan kapiya teslimat hizmeti vermektedir (Wheatley, 2014: 377).

2013 y1lında Barclays Bank, yüksek riskli olmaları nedeniyle 140'tan fazla İngiltere merkezli havale şirketini kapatmıştır. HSBC yetki alanlarındaki bazı havale şirketleriyle sözleşmesini sonlandırmış, Sunrise Community Bank ABD-Somali havalesini içeren tüm hesaplarını kapatmaya karar vermiştir. Ancak 2014 yılında G20 ülkelerinde 25 banka ve 82 IVTS tarafindan tamamlanan bir anket, AML ve CFT düzenlemeleri ihlalinin IVTS hesaplarının kapatılmasının en önemli nedeni olmadığını göstermektedir. Başlıca nedenler bankaların, kar marjlarının düşeceğinden ve olası bir ihlal de karşı karşıya kalabilecekleri cezai müeyyeyidelerden endişe duymalarıdır. Düzenleyici otoriteler ile bankacılık sektörü arasındaki ilişkiyi yöneten bu korku ve bankaların suçluları finansal sistem üzerinden takip etmede ortak olduklarını hissetmemeleri nedeniyle, finans sistemi muhafazakâr bir şekilde çalışmakta ve yüksek riskli müşteriler için hizmetlerini kısıtlamaktadır (Malakoutikhah, 2020: 672).

IVTS'nin risk azaltmaya tabi tutulması, çoğunlukla dezavantajlı kişilerin mali dışlanmasına yol açabilir ki bu CTF ile mücadelede etkili bir süreç değildir. Üstelik müşterileri vaka bazında incelemeden doğası gereği yüksek riskli olarak görmek adil de değildir. CTF çerçevesinin amacı, güvenli uluslararası havale hizmetlerine sahip olmak ve IVTS'nin düzenlenmiş finansal sistemle ilişkilerini kesmemesi için çaba sarf etmek olmalıdır (Malakoutikhah, 2020: 677).

De Goede (2003) Hawala'nın, paralel bir sistem veya yer altı bankacılık ağı olmaktan çok, Batı bankacılığının kurumlarına ve uygulamalarına sayısız yolla bağlı olduğunu, özellikle Hawala'nın Batı'daki göçmen işçilerin mali dışlanmasıyla ilişkilendirilmesi gerektiğini, Hawala söylemlerinin, uluslararası havale ağlarını suç haline getirirken, terörizmin finansmanıyla mücadelenin karmaşıklı̆̆ının küçümsenmesine yol açtığını belirtmiştir (De Goede, 2003: 522). Öte yandan Hawala, bir devlete insani amaçlı para gönderiminde de yararlı olabilmekte ve bu amaçla hem uluslararası kuruluşlar hem de STK'lar (sivil toplum kuruluşları) tarafindan kullanılabilmektedir (Maimbo, 2003: 13). Çünkü bankalar, insani yardım için bile olsa Irak, İran ve Suriye gibi bazı ülkelere para transferinde temkinli davranmaktadır. STK'lar uyumlu olma arzusuna sahip olsalar da bankalar tarafindan benimsenen düzenlemeler ve politikalar belirsiz olabilmektedir. Charity Finance Group tarafından 2017 y1lında yapılan ankete göre, STK'ların yüzde 79 'u nedenlerle ilgili net bir açıklama olmasa bile banka sistemine erişimde veya kullanımda transfer gecikmesi, hesapların kapatılması ve fonların dondurulması gibi sorunlar yaşamışlardır. Bu durumda, bankacılık sistemi STK'lar için uygun olmadığında, nakit kuryeler, Hawala, karaborsa ve özel banka hesapları gibi başka fon transferi yöntemlerinin kullanımı kaçınılmazdır (Malakoutikhah, 2020: 674).

Finansal kurumlar için lisanslama ve yasal gereklilikler resmi bankacılık sektörü etrafinda gelişmiştir. $\mathrm{Bu}$ gereklilikler, geleneksel IVTS'nin faaliyet gösterdiği benzersiz özellikleri (bknz Tablo 1) hesaba katmamıştır. Bu sorun, genel olarak tüm finansal kurumlar için daha yüksek AML ve CFT prosedürlerinin uygulanmasıyla 11 Eylül'den sonra daha da karmaşık hale gelmiştir. IVTS her zaman gayri resmi sektörde faaliyet göstermiştir ve bu nedenle, artan 
düzenlemeler tek başına bunu değiştiremeyecektir. Hükümetler, IVTS'ye karşı sert bir yaklaşım izledikleri sürece operatörler, tespit edilmekten kaçınmanın yollarını bulmaya ve kayıt dışı sektörde işlemlerini sürdürmeye devam edecektir. Düzenleyiciler, resmi bankacılık sisteminin mevcut haliyle birçok kişinin ihtiyaçlarını karşılayamayacağını anlamalıdır. IVTS finans sektörü içinde "özel” bir sınıftır ve bu şekilde düzenlenmesi gerekir. Büyük finansal kuruluşlar için tasarlanan uluslararası standartların, kayıt dıșı sektöre empoze edilmesi ve gerçekçi bir şekilde uygulanması mümkün değildir. $\mathrm{Bu}$ amaçla IVTS operatörleri için özel bir lisans sınıfı oluşturulmalı, sistemlerin çalıştığı yerel koşulları hesaba katan uluslararası standartlar geliştirilmeli, göçmen işçilerin geldiği bölgelerde banka hizmetleri arttırılmalı, göçmen işçilerin resmi sistemi kullanmaları için teşvikler sağlanmalıdır. Bu teşvikler, hesaplar için daha yüksek bir faiz oranı sağlamayı ve havale masraflarının kaldırılmasını içerebilir.

Modern IVTS'nin düzenlemeleri suç faaliyetlerini içermesi nedeniyle geleneksel IVTS'den farklı olmalıdır. Bu sistemlerin kullanımını tamamen ortadan kaldırmaya ve bunları kullandığı tespit edilen herkesi kovuşturmaya çaba gösterilmesi gerekmektedir. Modern IVTS'yi durdurmak için etkili politikalar, bankacılık, dış ticaret, döviz ve ticari mallar için karaborsalar, yolsuzluk ve narkotik dâhil olmak üzere, operasyonlarında yer alan çeşitli unsurları hesaba katmak olacaktır. Açıkçası bu çok kapsamlıdır ve hiçbir politika hepsini hesaba katamayacaktır. $\mathrm{Bu}$ nedenle, politika yapıcıların soruna geniş bakıș açısını koruması ve yalnızca bireysel alanlara karşı değil, aynı zamanda aralarındaki bağlantılara karşı da işleyecek tamamlayıcı politikalar tasarlaması hayati önem taşımaktadır. Uyuşturucu ticaretinden elde edilen gelirler bu sistemlerin çoğunun ayrılmaz bir parçası haline geldiğinden, uyuşturucu akışına özel dikkat gösterilmesi gerekmektedir. Uyuşturucu kullanımını azaltmak için hem arz hem de talep tarafinda önemli çaba sarf edilmelidir.

Sonuç olarak, IVTS'lere ilişkin mevcut uluslararası politikalar sorunlu ve tutarsızdır. 11 Eylül'den sonra bu sistemler, kullanımları ve işleyişleri konusunda tam bir anlayışa sahip olunmadan otomatik olarak karalanmıştır. Bu reaksiyon, geleneksel IVTS için uygun değildir. Etkili düzenleme, bu sistemlerin meşru kullanımlarını etkileyen ekonomik ve sosyal faktörleri dikkate almalıdır. IVTS yönetmeliğinin birincil amacı, bunların kullanımını yasaklamak veya erişilebilirliği sınırlandırmak değil, şeffaflığı ve hesap verebilirliği artırmak için mevcut süreci resmileştirmek olmalıdır.

\section{SONUÇ}

Hawala sistemi, Yakın ve Orta Doğu ülkeleri (başta Afganistan, Pakistan, İran, Irak, Suudi Arabistan ve Birleşik Arap Emirlikleri) ile güçlü tarihi, etnik, kültürel ve dini bağları olan para ve değer transfer sistemlerinden biridir. Batı bankacılık uygulamalarının başlamasından önce, bu sistem esas olarak Hindistan'da geliştirilmiştir. 20-21. yüzyıllarda Hawala sistemi üzerindeki en önemli etki, teknolojik ilerleme ve internetin yaygınlaşması ile meydana gelmiş, bu da Hawala sistemi aracılığıyla fon aktarımı için modern, yükseltilmiş bir modelin oluşumuna yol açmıştır.

11 Eylül 2001'de Dünya Ticaret Merkezi'ne yönelik terörist saldırılardan kısa bir süre sonra Hawala, haberlerde ve politik söylemde teröristlerin eylemlerini finanse edebildikleri önemli bir kanal olarak tespit edilmiştir. 11 Eylül'den sonra Hawala uluslararası basında "terörizm için kurulmuş bir bankacılık sistemi", bir "uluslararası yeraltı bankacılık sistemi" olarak tanımlanmıştır. Sistemin genellikle yasadışı finans için sağladığı yararlar yüzünden günümüze kadar varlığını sürdürdügü̈, Hawala sisteminin uyuşturucu ticareti, insan ticareti, terörizm ve yolsuzlukla bağlantılı olduğu yönünde görüşler bulunmaktadır.

Geleneksel IVTS, asli olarak finansal işlemlerde verimliliği ve güvenliği artırmak için geliştirilmiş yasal sistemler olarak yüzyıllardır faaliyet göstermiştir. IVTS şu anda birçok ülkede 
yasadışı olmasına rağmen, kullanımlarının kriminalize edilmesi tarihsel bir perspektifte nispeten yakın zamanda gerçekleşmiştir. Resmi bankacılık sistemleri gelişip düzenlenirken, geleneksel IVTS, düzensiz ve belgelenmemiş bir ortamda çalışan paralel bir sistem olarak dışarıda kalmıştır. IVTS'nin yasal kullanımı, göçmen işçi havalelerini, insani ve acil yardımları, iş gerekliliğini ve kişisel kullanımı içerir. Fonların asıl kaynağını veya nihai amacını gizlemeye çalışan suçlular ve terör örgütleri tarafindan geleneksel ve modern sistemlerin gayri meşru kullanımı bu meşru kullanımla çelişmektedir. IVTS'nin gayri meşru kullanımı kara para aklama, terör finansmanı, vergi kaçırma, kaçakçılık, silah ve uyuşturucu ticareti, yolsuzluk gibi yasadışı faaliyetleri içermektedir.

Yasadışı Hawala tarafından ortaya atılan tehditler önümüzdeki yıllarda artabilir. Hükümetler ana akım finansal kurumları gözetim altında tuttuğundan, suç unsurları muhtemelen Hawala gibi finansal sistemlere daha fazla yönelecektir. Yapılacak reformlar, bankacılık sistemine olan güveni artırmaya ve müşterileri Hawala'dan uzaklaştırmaya odaklanmalıdır. Gelişmekte olan ülkeler uyum sürecini tamamlamak için gerekli kaynak ve becerilerden yoksun olduklarından özellikle eğitim ve kapasite geliştirme konusunda desteklenmelidir. Hükümetler, Hawala'nın ana finans kurumlarıyla olan bağlantılarını kullanabilir ve gözetim altındaki alternatif havale sistemlerini teşvik edebilir. Para akışını izlemek ve daha iyi kontrol etmek için daha fazla uluslararası işbirliğine ihtiyaç bulunmaktadır.

$\mathrm{Bu}$ araştırmanın önemi, IVTS'nin gerekliliğini ve onları hem meşru hem de gayri meşru kullanımlar için arzu edilir kılan özellikleri anlama ihtiyacından kaynaklanmaktadır. Bunun kesin bir şekilde anlaşılması, IVTS'nin gelişmesine yol açan koşulların incelenmesine ve analiz edilmesine izin verecektir. Koşulların bilinmesi, yasal olmayan kullanımı sınırlamak ve meşru kullanımın neden olabileceği ekonomik zararı azaltmak için etkili düzenleyici politikaların uygulanmasına izin verecektir. Çalışma bu süreçte, kapsamlı ve faydalı IVTS düzenlemesinin nihai hedefine doğru daha fazla araştırmanın inşa edebileceği ilk adımı oluşturmaktadır. 


\section{KAYNAKÇA}

Akcora, C. G., Purusotham, S., Gel, Y. R., Mitchell Krawiec-Thayer, M. K. \& Kantarcioglu, M. (2020). How to not get caught when you launder money on Blockchain? https://arxiv.org/abs/2010.15082, erişim tarihi: 04.01.2021.

Dobayev, A., Igor, D. \& Tatiana, I. (2020). Criminological features of financial operations by the Havala system. https://cyberleninka.ru/article/n/criminological-features-of-financial-operations-by-the-havala-system, erişim tarihi: 04.01.2021.

Ballard R. (2006). Hawala: criminal haven or vital financial network. International Institute of Asian Studies. University of Leiden.http://crossasia-repository.ub.uni-heidelberg.de/263/1/iiashawala.pdf, erişim tarihi: 24.05.2020.

Ballard, R. (2005). Coalitions of reciprocity and the maintenance of financial integrity within informal value transmission systems: the operational dynamics of contemporary Hawala networks. Journal of Banking Regulation, 6 , 319-352.

Bowers, C. B. (2009). Hawala, money lending, and terrorist financing: micro lending as an end to illicit remittance. Denver Journal of International Law and Policy, 37, 377-419.

Burns, A. (2006). International relations perspectives on anti money laundering governance http://www.alexburns.net/Files/IRAML.pdf, erişim tarihi: 24.05.2020.

Catrinescu, N., Leon-Ledesma, M., Piracha, M. \& Quillin, B. (2009). Remittances, institutions, and economic growth. World Development, 37(1), 81-92.

Choucri N. (1986). The hidden economy: A new view of remittances in the Arab world. World Development, 14, 697712 .

Cooper, K. \& Walker, C. (2016). Security from terrorism financing: modsels of delivery applied to informal value transfer systems. British Journal of Criminology, 56(6), 1125-1145.

Corselli, L. (2020). Italy: money transfer, money laundering and 1ntermediary liability. Journal of Financial Crime, https://doi.org/10.1108/JFC-10-2019-0137, erişim tarihi: 04.01.2021.

De Goede, M. (2003). Hawala discourses and the war on terrorist finance. Environment and Planning D: Society and Space, 21, 513-532.

El Qorchi, M. (2002). Hawala. Finanzas Desarrollo, 39, 31-33.

Elmi M.A. \& Ngwenyama O. (2020). Examining the use of electronic money and technology by the diaspora in international remittance system: A case of Somali remittances from Canada. Electron $j$ inf syst dev ctries. e12138. https://doi.org/10.1002/isd2.12138, erişim tarihi: 04.01.2021.

FATF (2013). The role of Hawala and other similar service providers in money laundering and terrorist financing. FATF Report, https://www.fatf-gafi.org/documents/documents/role-hawalas-in-ml-tf.html, erişim tarihi: 24.05.2020.

FATF (2012-2020). International standards on combating money laundering and the financing of terrorism \& proliferation The FATF recommendations. https://www.fatfgafi.org/media/fatf/documents/recommendations/pdfs/FATF\%20Recommendations\%202012.pdf, 18.03.2021.

Gediz Oral, B. \& Koç, Ö. E. (2010). Terörün finansman kaynaklarıyla mücadele. Terör Ekonomisi. Ed. Ramazan Gökbunar \& Ali Rıza Gökbunar. ISBN: 978-605-377-255-2. İstanbul. Beta Basım Yayın.

Gediz Oral, B. (2016). Terörizmin finansmanıyla mücadelede vergilendirme ve terör ilişkisi. Celal Bayar Üniversitesi Sosyal Bilimler Enstitüsü Dergisi. 14 (4), 341-358.

Gediz Oral, B. \& Gökbunar, A. R. (2017). Karapara aklamanın (politik) araçları: yolsuzluk, organize suç ve mücadelede mali önlemler. Yönetim ve Ekonomi, Celal Bayar Üniversitesi İktisadi ve İdari Bilimler Fakültesi Dergisi, 24(1), 89-114.

Gediz Oral, B. \& Yeşilkaya, Y. (2020). Küresel tehditler: karapara aklama ve terörizmin finansmanıyla mücadele: Basel Anti- Para Aklama (AML) Endeksi. Küreselleşmenin Finansal Ve Reel Yaşama Yansımaları. Ed. Selim Duramaz. ISBN: 978-605-242-808-5. İstanbul. Beta Basım Yayın.

Gordon, R. \& Rossman, C. (2009). Foreword: combating terrorist financing. Case Western Reserve Journal of International Law, 41(1).

Gräbner, C., Elsner, W. \& Lascaux, A. (2020). Trust and social control: sources of cooperation, performance, and stability in informal value transfer systems, Computational Economics https://doi.org/10.1007/s10614-020-09994-0, erişim tarihi: 04.01 .2021 . 
Lambert, L. (2002). Asian underground banking scheme: A field note. Journal of Contemporary Criminal Justice, 18, $358-369$.

Levi, M. \& Reuter, P. (2008). Money laundering, in Michael Tonry (ed.) Handbook of Crime and Public Policy. New York: Oxford University Press.

Maimbo, S. M. (2003). The money exchange dealers of kabul a study of the Hawala system in Afghanistan. The World Bank, USA.

Malakoutikhah, Z. (2020). Financial exclusion as a consequence of counter-terrorism financing. Journal of Financial Crime, 27(2), 663-682.

Milosevic, B. (2016). Money laundering as a form of economic crime in the role of financing terrorism. Facta Universitatis, Law and Politics, 14(4), 549-560.

Nakhasi, S. S. (2007). Western unionizing the Hawala: the privatization of Hawalas and lender liability. Northwestern Journal of International Law and Business, 27, 475-496.

Parandeh, S. C. (2009). Hawala: The Fund Transfer Methodology that Evades Surveillance. Journal of Corporate Treasury Management, 3, 22-32.

Passas, N. (2003). Informal value transfer systems, terrorism and money laundering. report to the national institute of justice. Boston: Northeastern University, https://ssrn.com/abstract=1327839, http://dx.doi.org/10.2139/ssrn.1327839, erişim tarihi: 24.05.2020.

Passas, N. (2006). Fighting terror with error: the counter-productive regulation of informal value transfers. Crime, Law and Social Change, 45, 315-336.

Passas, N. \& Maimbo, S.M. (2008) The design, development, and implementation of regulatory and supervisory frameworks for informal fund transfer systems. Countering the Financing of Terrorism. Ed. T.J. Biesterker and S.E. Eckert, Abingdon, UK: Routledge, 174-192.

Razavy, M. (2005). Hawala: An underground haven for terrorists or social phenomenon? Crime, Law and Social Change, 44, 277-299.

Resmî Gazete 26999 (16.09.2008). Suç Gelirlerinin Aklanmasının ve Terörün Finansmanının Önlenmesine İlişkin Yükümlülüklere Uyum Programı Hakkında Yönetmelik, https://www.resmigazete.gov.tr/eskiler/2008/09/200809161.htm, erişim tarihi: 11.03.2021.

Rusten Wang, J. (2011). Regulating Hawala: A comparison of five national approaches. Journal of Money Laundering Control, 14, 210-224.

Ryder, N. (2015). The financial war on terrorism: a review of counter-terrorist financing strategies since 2001. Routledge, New York.

Schneider, F. (2010). Turnover of organized crime and money laundering: some preliminary empirical findings. Public Choice, 144, 473-486.

Schramm, M. \& Taube, M. (2003). Evolution and institutional foundation of the Hawala financial system. International Review of Financial Analysis, 12, 405-420.

Shehu, A. Y. (2004). The Asian alternative remittance systems and money laundering. Journal of Money Laundering Control, 7, 175-185.

Stepanova E.A. (2005). The role of drug business in the political economy of conflict and terrorism. Ves'Mir Pub. Moscow.

Teicmann F. \& Falker, M. C. (2020). Weaknesses of underground banking systems. In: Popkova E., Sergi B. (eds) Artificial Intelligence: Antropogenic Nature vs. Social Origin. ISC Conference- Volgograd 2020. Advances in Intelligent Systems and Computing, 1100. Springer, Cham. https://link.springer.com/chapter/10.1007/978-3-03039319-9_55, erişim tarihi: 22.01.2020.

Vaccani, M. (2009). Alternative remittance systems and terrorism financing: 1ssues in risk management. Working Paper No 180, World Bank.

Valeri, M., Fondacaro, R., Angelis, C. De \& Barella, A. (2020). The use of cryptocurrencies for Hawala in the Islamic finance. European Journal of Islamic Finance. http://www.ojs.unito.it/index.php/EJIF, erişim rarihi: 02.01.2021.

Van de Bunt, H. (2008). A case study on the misuse of Hawala banking. International Journal of Social Economics, 35, 691-702.

Weber C. (2002). Flying planes can be dangerous. Millennium, 31(1), 129-147. 
Wheatley (2014). Ancient banking, modern crimes: how Hawala secretly transfers the finances of criminals and thwarts existing laws, University of Pennsylvania Journal of International Law, 26(2), 348-378.

World Bank (2020). Remittance Prices Worldwide, 2020, https://remittanceprices.worldbank.org/sites/default/files/rpw_main_report_and_annex_q42020.pdf, erişim tarihi: 24.01 .2021

World Bank. (2020). Annual Remittance Data, https://www.worldbank.org/en/topic/migrationremittancesdiasporaissues/brief/migration-remittances-data,_erişim tarihi: 15.03.2021.

Yücebaş, Ö. (2011). Suç ekonomisi ve terörörün finansmanı. ISBN: 978-605-5593-37-7. Ankara. Turhan Kitabevi. 


\section{Extended Summary}

\section{The Role of Informal Value Transfer Systems in Money Laundering and Financing Terrorism: The Hawala System}

In this study, the system called Hawala, which is among the most important IVTS in the world, is explained. The study focuses on how to develop effective regulatory policies for illegal distribution while protecting the legitimate aspects of these systems. First we analyze the Hawala system, how it works, and the popular test, Hawala's money laundering and terrorist financing crimes, then summarize and criticize the legal and regulatory regimes aimed at combating Hawala, identify the challenges of the fight and strategies are presented to restrict the illegal divisions of Hawala.

The pragmatism of the subject requires thinking more about the phenomenon and establishing an effective system against it. In this context, it seems to be one of the most important tasks in the context of examining the world experience, creating our own researches in order to ensure the national security of the country in economic and financial areas, determining the use of the Hawala system to legalize the proceeds of crime and to finance terrorism. The aim of this study is to analyze the use of traditional and modern IVTS specific to the Hawala system to identify specific macro indicators and conditions responsible for their development and continuous use. Identifying these indicators will allow regional, national and international institutions and organizations to identify the emergence or existence of IVTS and focus on their efforts to develop effective regulatory policies to limit illicit use while preserving the legitimate aspects of these systems.

The importance of this research stems from the need to understand the necessity of IVTS and the characteristics that make them desirable for both legitimate and illegitimate uses. A precise understanding of this will allow the study and analysis of the specific conditions that led to the development of IVTS. Knowing the terms will then allow effective regulatory policies to be implemented to limit illegal use and reduce the economic damage that legitimate use can cause.

Informal Value Transfer Systems (IVTS) are financial services for moving funds or values from one region to another through a personal network associated with a specific geographic area. IVTS is a widespread system worldwide and is used for a variety of legitimate and illegitimate purposes. One of the most common types of IVTS is the Hawala system, which is a globally valid payment method associated with money laundering and financing of terrorism. Hawala is an alternative or parallel money transfer system, therefore it is often referred to as "underground banking". Initially, Hawala networks provided secure money transfers for merchants traveling along the Silk Road in Asia centuries ago. However, after the terrorist attacks on the US World Trade Center on September 11, 2001, Hawala was defined as "a banking system established for terrorism", an "international underground banking system" in the international press. The fact that Hawala has some unique features also had an effect on these definitions. International concerns have increased about the use of Hawala in criminal activities for purposes such as money laundering and financing of terrorism, due to its features such as complex transactions, fast and cheap transactions, and allowing anonymous transfer of capital to another country.

While traditional systems have existed for centuries and are mainly used for legitimate transactions such as remittances, modern systems have been developed primarily for illegitimate purposes such as money laundering and tax evasion. It is important to note that even the legal use of IVTS can have negative effects. The large amount of funds that go through legitimate transactions can hurt the economies of developing countries by bypassing the official financial sector, avoiding taxes and weakening the currency. On the other hand, traditional IVTS is 
definitely needed due to the limited or no capacity of the official banking system to meet the financial needs of the people especially in developing countries.

Traditional Hawala was developed to meet the legitimate needs of businesses and individuals and at times became the official banking system in the Middle East and South Asia. Conversely, modern Hawala is developed as purely criminal systems and has no legitimate purpose. Traditional systems have predominantly positive effects on the communities in which they operate, modern systems have the opposite negative effects. Attention is drawn to the use of the Hawala system in criminal activities (terrorist financing, money laundering, tax evasion, drug trade, arms trade, precious stone-mineral smuggling, informal economy, corruption, etc.).

The strategies to combat illegal Hawala brokers fall into two categories: research techniques and economic incentives to develop alternatives to Hawala. In both cases, developed countries and international organizations should assist states (mainly developing countries) that lack skills or funds. These aids should be particularly in the fields of training and capacity building.

Current international policies regarding IVTS are problematic and inconsistent. These systems were automatically scribbled after $9 / 11$ without having a full understanding of their use and operation. This reaction is not suitable for conventional IVTS. Effective regulation should take into account economic and social factors affecting the legitimate use of these systems. The primary purpose of the IVTS regulation should not be to prohibit their use or limit accessibility, but to formalize the current process in order to increase transparency and accountability.

IVTS is a "special" class within the financial sector and should be regulated as such. International standards designed for large financial institutions cannot be imposed on the informal sector and cannot be expected to be applied realistically. For this purpose, a special license class should be established for IVTS operators, international standards should be developed taking into account the local conditions in which systems operate, bank services should be increased in the regions where migrant workers come from, and incentives should be provided for migrant workers to use the official system. 
Optimum Journal of Economics and Management Sciences, Vo1. 8, No. 2- https://dergipark.org.tr/tr/pub/optimum Gediz Oral - The Role of Informal Value Transfer Systems in Money Laundering and Financing Terrorism: The Hawala System 